УДК 336.22

\title{
ВОЗМОЖНЫЕ ПУТИ РАЗВИТИЯ НАЛОГОВОЙ СИСТЕМЫ В РОССИЙСКОЙ ФЕДЕРАЦИИ
}

\section{Габбасова Ирина Маратовна студент}

\section{Салькина Альфия Ринатовна}

доцент

ФГАОУ ВО «Самарский государственный экономический университет»

\begin{abstract}
Аннотация: В статье описаны возможные пути развития налоговой системы РФ, в частности, таких ее элементов, как система налогообложения и налоговый контроль. Предлагается законодательное закрепление новой категории налогоплательщиков. Освещена новая процедура в сфере налогового контроля - налоговая медиация. Отмечено нововведение 2021 года - введение прогрессивной ставки по НДФЛ.

Ключевые слова: налоговая система РФ, налоговая медиация, крупные налогоплательщики, прогрессивная система налогообложения.

\section{POSSIBLE WAYS OF DEVELOPMENT OF THE TAX SYSTEM IN RUSSIA}

\section{Gabbasova Irina Maratovna Alfiya Rinatovna Salkina}

\begin{abstract}
The article describes the possible ways of development of tax system of RF, in particular, such elements as taxation system and tax control. Legislative consolidation of a new category of taxpayers is suggested. The new procedure in the sphere of tax control - tax mediation - is highlighted. It is noted the innovation of 2021 - the introduction of a progressive rate of personal income tax.

Key words: tax system of the Russian Federation, tax mediation, large taxpayers, progressive system of taxation.
\end{abstract}


От эффективности работы налоговой системы государства зависит количество налоговых поступлений в бюджет, которые и формируют его доходную часть до $95 \%$ в зависимости от бюджетно-налоговой политики государства. Эта особенность определяет одну из особенностей налоговой системы развитого государства в современном мире - это ее перманентное совершенствование.

Налоговая система РФ - совокупность всех налогов и сборов, законодательно установленных в России, государственных органов, взимающих их, и непосредственно плательщиков налогов и сборов [1]. Налоговая система состоит из таких элементов, как система налогообложения, система налогового контроля и система наказания за налоговые правонарушения. Проанализируем, как может развиваться каждый из этих элементов.

Согласно ст. 82 НК РФ, налоговый контроль - деятельность уполномоченных органов по контролю за соблюдением законодательства о налогах и сборах в порядке, установленном Налоговым кодексом РФ [2]. К формам налогового контроля в России на данный момент можно отнести налоговые проверки, получение объяснений налогоплательщиков, налоговых агентов и плательщиков сбора, плательщиков страховых взносов, проверку данных учета и отчетности и осмотр помещений и территорий, используемых для извлечения дохода (прибыли), налоговый мониторинг, налоговую медиацию и иные формы, закрепленные в НК РФ. Две последние формы являются нововведениями последних пяти лет, а потому в ч. 1 ст. 82 НК РФ они не перечислены. Налоговый мониторинг, представляющий собой дистанционный контроль за налоговой отчетностью организации, практикуется в РФ с 2016 года. Налоговая медиация еще не закреплена в Налоговом кодексе, однако применяется ФНС в качестве досудебной стадии урегулирования спора с налогоплательщиком с 2020 года [3]. Суть механизма медиации заключается в привлечении третьей стороны (медиатора) независимого эксперта, который помогает сторонам выработать определенное соглашение по претензиям налоговой службы, при этом принятие или отклонение условий разрешения спора целиком остается в ведении сторон. Законодательной базой для проведения такой процедуры служит Федеральный закон от 27.07.2010 № 193-Ф3 «Об альтернативной процедуре урегулирования споров с участием посредника (процедуре медиации)». 
Медиация - возможность избежать выездной налоговой проверки по вопросам и периодам, на которые распространяется действие соглашения, для налогоплательщика и способ повысить эффективность работы для сотрудников налоговых органов, которые будут освобождены от необходимости поиска налогоплательщика и налаживания контакта с ним. Данная форма налогового контроля еще не распространена в России так широко, как в некоторых зарубежных странах, однако уже сейчас можно говорить о том, что налоговая медиация - перспективный метод разрешения конфликтов и разногласий между налоговыми органами и налогоплательщиками. Развитие инструментов налогового контроля, подобных медиации, позволит успешно продвигаться к новым отношениям между ФНС и налогоплательщиками - к сотрудничеству и диалогу, построенному на принципах добровольности и взаимоуважения.

Интересной для реформаторов налоговой системы в России может показаться градация налогоплательщиков в таких государствах, как, например, Нидерланды и Австрия. В налоговой системе этой страны предусмотрено наличие нескольких критериев, соответствие хотя бы одному из которых означает причисление организации к крупным налогоплательщикам. Такими критериями выступают, в частности, участие акции компании в торгах на Амстердамской бирже, средневзвешенная фискальная стоимость компании более 12,5 млн евро (1 миллиард рублей) или сфера деятельности компании - финансы, газ, нефть и некоторые другие [4]. Соответствие двум и более критериям одновременно причисляет организацию к суперкрупным налогоплательщикам. В соседней Австрии проверкой крупных налогоплательщиков занимается специальная налоговая служба для крупных предприятий. В России существует термин «крупнейший налогоплательщик» и функционируют отдельные Межрегиональные инспекции по крупнейшим налогоплательщикам, однако в данную категорию на 2021 год входят лишь те организации, суммарный объем доходов которых превышает 10 миллиардов рублей. При введении в налоговое законодательство термина «крупный налогоплательщик» перечень организаций, не входящих в категорию «крупнейших», однако так же нуждающихся в пристальном внимании со стороны ФНС, существенно увеличится. Кроме того, поручая инспекцию крупных и (или) крупнейших налогоплательщиков отдельным подразделениям, ФНС может повысить 
производительность труда своих сотрудников, поскольку выбранные специалисты будут накапливать опыт в проверке компаний определенного типа и масштаба и быстрее справляться с поставленными задачами.

Наконец, из видимых тенденций в развитии налогового законодательства и налоговой системы России в целом необходимо отметить такое новшество, как закрепление прогрессивной ставки налога на доходы физических лиц для суммы годового дохода резидента свыше 5 миллионов рублей, равной $15 \%$.

В целом система налогообложения в РФ пропорциональна, однако введение прогрессивной ставки одного из ключевых налогов может повлечь за собой глобальные изменения: внедрение прогрессивной шкалы для исчисления других налогов, создание более разветвленной системы ставок и так далее. Прогрессивная шкала налогообложения - наиболее справедливая по отношению $\mathrm{\kappa}$ налогоплательщикам $\mathrm{c}$ различным уровнем дохода и социальным положением. В большинстве развитых стран установлена прогрессивная шкала налогообложения со множеством ставок, исходя из доходов и иных критериев. Например, минимальная ставка подоходного налога в Новой Зеландии, одной из самых успешных налоговых систем мира, равна 10,5\%, если годовой доход резидента не превышает 14000 новозеландских долларов (705000 рублей) [5]. Максимальная ставка с 1 апреля 2021 года составляет 39\%, доход резидента при этом должен превышать 180000 новозеландских долларов (9063000 рублей) в год [6]; иные ставки равны $17,5 \%, 30 \%$ и $33 \%$.

По результатам исследования выявлены следующие возможные пути развития российской налоговой системы. Во-первых, внедрение таких инструментов, как налоговая медиация, способствует развитию партнерских отношений между налоговыми органами и налогоплательщиками и делает процесс разрешения споров более быстрым и комфортным для обеих сторон. Во-вторых, предложено ввести в налоговое законодательство категорию «крупного налогоплательщика», что позволит увеличить эффективность сбора налогов с лиц, годовой доход которых менее 10 млрд рублей, однако также существенен при исчислении налоговых платежей. В-третьих, отмечена тенденция налогового законодательства РФ к введению прогрессивной системы налогообложения, в частности, введению прогрессивной ставки по 
НДФЛ с 1 января 2021 года, что в дальнейшем может повлечь положительные изменения во всей системе налогообложения России.

\section{Список литературы}

1. Портал новостей в области бухгалтерского учета, налогов и права // Режим доступа: https://nalog-nalog.ru/.

2. Налоговый кодекс Российской Федерации (часть первая) от 31.07.1998 N 146-Ф3.

3. Статья «Медиация - новое слово в налоговом контроле». Официальный сайт ФНС России // Режим доступа: https://www.nalog.gov.ru/ rn63/.

URL: https://www.nalog.gov.ru/rn78/news/activities_fts/10194093/.

4. Вылкова Елена Сергеевна Передовой опыт налогового администрирования в различных странах // Известия БГУ. 2014. №5. URL: https://cyberleninka.ru/article/n/peredovoy-opyt-nalogovogo-administrirovaniya-vrazlichnyh-stranah.

5. Официальный сайт GSL, международной аудиторской и консалтинговой компании // Режим доступа: https://gsl-news.org/.

6. Официальный сайт аудиторской компании EY (Ernst\&Young). Отчет за апрель 2021 // Режим доступа: https://www.ey.com/en_gl.

(C) Габбасова И.М., Салькина А.Р., 2021 